$$
\text { JOES } \begin{aligned}
& \begin{array}{l}
\text { Journal } \\
\text { of Educational } \\
\text { Study }
\end{array}
\end{aligned}
$$

ISSN 2798-0650

Volume 1 Issue 22021

DOI: $10.36663 /$ joes.v1i2.145

\title{
An Analysis of Students' Reading Skill Using Electronic Book to Improve Students’ English Reading Literacy in Elementary School
}

Made Angga Dwipayana, STKIP Agama Hindu Singaraja, Indonesia dwipayanaangga19@gmail.com

\begin{abstract}
This study was analyzed student reading skill using electronic book to improve students' English literacy in elementary school. The subjects of the study were five articles are chosen from how the research to implement electronic book as a teaching tool to improve student reading skill. The data obtained was descriptive qualitative research. This research described the result of using $e$ book as a teaching tool in elementary school. The data in this study is taken from five articles that examine the use of e-book in elementary school. The result of the study showed that the interesting way to implement reading literacy for teacher in the classroom is using e-book. Electronic book can make students more interested in reading with many features. In addition, the effects of an ebook reading on the following aspects: 1) vocabulary increase, and 2) motivation and interest on reading.
\end{abstract}

Keywords: English Literacy, Reading Skill, Electronic Book

\section{Introduction}

English is an international language that people used to communicate all over the world. Indonesia knows English as a foreign language. In this globalization era, English has been used as the language of science, technology, academia, youth culture, mass media, and business among people from different nations, languages, or cultures on various occasions requiring them to be good at its every skill (Crystal, 2003; Graddol, 2006) in Ayu et al. (2017).

Learning English literacy for children in elementary school will really help them to develop and follow the development of a world that uses English as an international language. According to Jones \& Brown (2011), reading skills for children are critical for future academic and personal growth. The opportunity to realize English literacy, especially for reading skills, will make children more open to the world. 


\section{JOES $\mid \begin{aligned} & \text { Journal } \\ & \text { of Educational } \\ & \text { Study }\end{aligned}$}

ISSN 2798-0650

Volume 1 Issue 22021

DOI: 10.36663/joes.v1i2.145

Nowadays, literacy is one of the problems that must receive special attention in Indonesia. This is because in the last few decades, the competitiveness of the Indonesian nation in the midst of other nations tends to be less competitive. This reality is reflected in the comparison of the Human Development Index (HDI). Tjalla (2011) in Kharizmi (2015) suggests several international studies that describe this condition, such as the research conducted by the Program for International Students Assessment (PISA) on the literacy skills (mathematics, science, and language) of students from various worlds in a row. In 2003, 2006, 2009, and 2012. Specifically for language literacy, in 2003 the reading literacy achievement of Indonesian students was ranked $39^{\text {th }}$ out of 40 countries, in 2006 it was ranked $48^{\text {th }}$ out of 56 countries, in 2009 it was ranked $4^{\text {th }} .57$ out of 65 countries, and in 2012 it was ranked $64^{\text {th }}$ out of 65 countries. The next research is research conducted by the Progress in International Reading Literacy Study (PIRLS) in 2006. PIRLS conducted a study of 45 developed and developing countries in the field of reading in fourth grade elementary school children around the world under the coordination of The International Association for the Evaluation of Educational Achievement (IEA) and obtained results that put Indonesia in $41^{\text {st }}$ place.

The results of these international studies show that the literacy skills of Indonesian students who represent the Indonesian people in general are low, especially in terms of language literacy. Thus, to create the students are able to access to read for a particular purpose and to literacy, creating themselves become self-directed and independent learners, the students should understand how to use, create and apply what they read and write comprehensively and applicable to the real world (Khairuddiniyah, 2017).

Considering that literacy is important for the future, the students are also need assume to acquire and develop English literacy not only on print books. The students' need a new teaching tool for English literacy activities might contribute to their English literacy development. Electronic book or e-book can be used for teaching reading in this digital era. According to Reinking \& Watkins (2000) in Ciampa (2012), to stimulate the children's reading orientation and involvement in reading, electronic storybooks let children activate reading of words, phrases, or pages in any order they want and are typically equipped with sound and animations that are activated by the child. Although there is evidence to suggest that the features embedded within ebooks contribute to children's early reading development, further research documenting students' experiences with, attitudes toward, and their motivation for reading these digital texts in the early primary grades are warranted (Ciampa, 2012).

Based on this problem, the researcher is interested in analyzing research about the use of electronic books as a teaching tool. The researcher wants to know how the implementation and effects of using e-book as a teaching tool in elementary school. 


\section{JOES $\begin{aligned} & \begin{array}{l}\text { Journal } \\ \text { of Educational } \\ \text { Study }\end{array}\end{aligned}$}

ISSN 2798-0650

Volume 1 Issue 22021

DOI: $10.36663 /$ joes.v1i2.145

Literacy is the ability to read, write, view, comprehend, discuss, create, listen and respond in a way that enables individuals to communicate effectively (UNICEF, 2000; UNESCO, 2005, 2014) in Thanyathamrongkul et al. (2018). Learning English literacy for children in elementary school will really help them to develop and follow the development of a world that uses English as an international language.

Reading is a process which is conceptualized as the decoding of printed symbols into phonological forms so as to understand the meaning of the printed texts (Koda, 2007; Ziegler \& Goswami, 2006) in Fathi (2020). The opportunity to realize English literacy, especially for reading skills, will make children more open to the world.

E-books are print books that have been completely converted to or originated in a digital format (Grudzien \& Casey 2008) in Jones \& Brown (2011). Nowadays, electronic book is available through two main sources: online websites and personal electronic devices. This device allows readers to download books, magazines, and newspapers in less than one minute more than two hundred thousand titles are available for download.

In the first article written by Troy Jones and Carol Brown (2011), electronic books (ebooks) are gaining popularity for personal reading. Options for access to a large selection of book titles and "anytime/anywhere" reading choices have added to the increased use of e-books. For this study, 22 third-grade students completed satisfaction surveys and reading comprehension tests on three separate reading sessions: one traditional print-based and two e-book titles. Indicators of reading engagement included motivation for independent reading and comprehension as measured by standardized tests on the print book and both e-books. Results showed that format was not as important as students' identification with setting, characters, and theme of the book. Students did, however, indicate a preference for e-books when given the option of a wide selection of titles and the freedom to choose their own e-book. Students further indicated a preference for the amenities associated with e-book reading such as pop-up definitions and pronunciations of words, automatic page turning, and the option of read-aloud narration. The authors concluded that children quickly become comfortable with e-books and welcomed the technology. However, they are not completely ready to disregard print books.

Meanwhile, in the second article written by Katia Ciampa (2012), beginning readers' motivation to read and the texts that students choose to read impact on their literacy achievement and willingness to engage with reading activities in the primary years of schooling. This study investigated the e-book reading experiences of eight grade 1 students. Eight students were given ten 25 minutes sessions with the software programs over 15 weeks. Qualitative data were collected from students, teachers, and parents through questionnaires, interviews, observations and field notes. The results suggest the promise of electronic books in enhancing the reading motivation of beginning readers. 


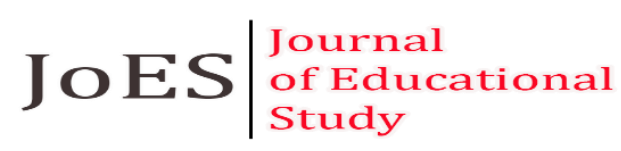

ISSN 2798-0650

Volume 1 Issue 22021

DOI: 10.36663/joes.v1i2.145

In the third article written by Yu-Ju Fu, Shu-Hui Chen, Shyh-Chyi Wey, Shu-Chu Chen (2014), the prevalence of web-based applications and the use of multimedia in school make learning and teaching through the Internet a popular method in education (Ferdig, 2005). To keep in line with the trend, the purpose of the study was to explore the effects of reading strategy instruction via electronic storybooks on EFL elementary school students' reading comprehension, their strategy use and their viewpoints toward electronic storybooks-based reading strategy instruction. Fifty-seven Taiwanese EFL fourth graders from two intact classes were chosen and assigned as an experimental group and a control group. The experimental group received a tenweek reading strategy instruction whereas the control group did not engage in any strategy training. The experimental group were taught seven reading strategies, which were practiced in small groups. The instruments included one STYLE proficiency test, five reading comprehension tests, and questionnaires of strategy use and an attitude questionnaire toward e-books based reading strategy instruction. Results indicated that after reading strategy instruction, the experimental group performed better than the control group in story comprehension, but without significance. However, they significantly outperformed the control group in strategy use. Also, the experimental group had positive attitude toward e-books based reading strategy instruction. Pedagogical implications were provided.

In the fourth article written by Bee Choo Yee and Nurul Syazana binti Zainuddin (2018), the research is an Action Research of using the Story Jumper as an E-book to improve the reading comprehension among Year 4 pupils in one of the primary schools in Malaysia. The participants involved were twenty pupils consisting of seven males and thirteen females. Three data collection methods employed were pre-test and post-test, pupils' work and teacher's reflective journal. The findings showed that the use of E-book had increased the level of understanding in reading comprehension among the research participants. The mean for the pre-test and post-test had increased from 45.83 to 93.33 . The pupils' work indicated positive improvements in terms of their level of understanding and responses in reading. It was also found from the reflective journal that the research participants had participated actively in the learning process and their level of motivation was also increased. The implication is to use E-book in the teaching of reading skills among the primary school learners.

And in the fifth article written by Yoon, Tecnam (2013), the purposes of the study are to explore the effects of an e-book reading on the following aspects: 1) vocabulary increase over the experiment period, and 2) the changes of affective factors on learning English through an e-book. In this e-book based study, sixty two Korean elementary school students were given ten weeks of instruction and provided with e-book reading materials. In order to evaluate students' vocabulary ability, pre- and post-tests were conducted with 30 questions. Also, pre- and post-surveys, interview and class observation were administered in order to measure the changes of affective factors. The results showed that: (1) with an e-book reading, vocabulary knowledge has increased; 


\section{JOES $\mid \begin{aligned} & \text { Journal } \\ & \text { of Educational } \\ & \text { Study }\end{aligned}$}

ISSN 2798-0650

Volume 1 Issue 22021

DOI: $10.36663 /$ joes.v1i2.145

(2) the affective factors such as motivation and interest on reading and English learning have been remarkably elevated. The study proves that an e-book reading or teaching English with an e-book can be of benefit to ESL/EFL learners.

Researcher got the comprehension for using electronic book as the teaching tool to improve reading skill in elementary school. These are feasible to be applied, especially if students are welcomed with technology because it will quickly invite children's interest to learn reading.

\section{Method}

In this study, the researcher used descriptive qualitative research design to answer the problem. As Williams (2007:66) in Murtadho (2018) theorized that "descriptive research approach is a basic research method that examines the situation, as it exists in its current state". In other words, the result of this descriptive research is description of the data at moment. This research described the result of using e-books as a teaching tool in elementary school. The data in this study is taken from five articles that examine the use of e-books in elementary school.

Qualitative research method is used in this study. According to Mack et al. (2005:1) in Murtadho (2018) stated that "Qualitative research is especially effective in obtaining culturally specific information about the values, opinions, behaviors, and social contexts of particular populations". In other words that qualitative research is used to get information from particular population. The data is obtained to find the social context and specific people.

Research procedures inform how research is carried out. Creswell (2012) stated that "in qualitative inquiry is not to generalize to a population, but to develop an in-depth exploration of a central phenomenon" (p.206). The data in this study will be in the form of descriptive qualitative data and use qualitative data procedure for the data analysis.

The instruments used in the study included five articles. First, Troy Jones and Carol Brown (2011) written an article entitled "Reading Engagement: A Comparison between E-books and Traditional Print Books in An Elementary Classroom". Second, Katia Ciampa (2012) written an article entitled "Reading in the Digital Age: Using Electronic Books as a Teaching Tool for Beginning Readers". Third, Yu-Ju Fu, Shu-Hui Chen, Shyh-Chyi Wey, Shu-Chu Chen (2014) written an article entitled "The Effects of Reading Strategy Instruction via Electronic Storybooks on EFL Young Readers' Reading Performance”. Fourth, Bee Choo Yee \& Nurul Syazana binti Zainuddin (2018) written an article entitled "The Use of E-book to Improve Reading Comprehension among Year 4 Pupils". Fifth, Yoon, Tecnam (2013) written an article entitled "Beyond the traditional reading class: The application of an e-Book in EFL English classroom".

Triangulation technique is used by researcher that is commonly used in qualitative approach. Triangulation refers to the use of multiple methods or data sources in qualitative research 


\section{JOES $\mid \begin{aligned} & \text { Journal } \\ & \text { of Educational } \\ & \text { Study }\end{aligned}$}

ISSN 2798-0650

Volume 1 Issue 22021

DOI: 10.36663/joes.v1i2.145

to develop a comprehensive understanding of phenomena (Patton, 1999) in Carter et al. (2014). The researcher used the technique of triangulation in this study.

Triangulation technique is a technique examined evidence from many sources and use it to build a coherent justification (Creswell, 2012:286). Triangulation also has been viewed as a qualitative research to test validity through the convergence of information from different sources. Denzin (1978) and Patton (1999) in Carter et al. (2014) identified four types of triangulation: (1) method triangulation, (2) investigator triangulation, (3) theory triangulation, (4) data source triangulation.

1. Method Triangulation

Method triangulation refers to researcher uses more than one method in the research. Cohen (2000: 113) explained "Method triangulation is using the same method on different occasions or different methods on the same object of study". Thus, methodological triangulation is making different method to get validity of data.

2. Investigator Triangulation

Investigator triangulation means technique that uses more than one researcher in collecting and analyzing data. From some researcher's view in interpreting information and collecting the data, the validity of data can be increased.

3. Theory Triangulation

Theoretical triangulation means the researcher compares the data finding with perspective theory that is relevant. Here, the researcher is demanded to have expert judgment to compare the finding of research with the certain theory.

4. Data Source Triangulation

In source triangulation, the researcher uses many sources or participants to get the accuracy of data.

From those types of triangulation, the researcher used theory triangulation and data source triangulation to get validity of data. The researcher compared the data finding with perspective theory that is relevant and used many sources to get the accuracy of data.

To analyze the data, the researcher uses descriptive qualitative to analyze data. According to Sugiyono (2008: 245), there are three activities to analyze data in descriptive qualitative research. Those activities are data reduction, data display, and conclusion drawing/verification. Based on those statements, the researcher divides the activity in analyzing data into three activities, they are data reduction, data display, and conclusion drawing.

In short, the steps in analyzing the data are: (1) the researcher collects the data from the five articles. Afterward, the researcher selects, identify, and focuses on the data by referring to 


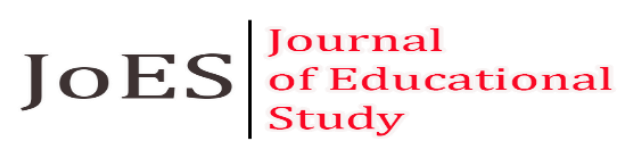

ISSN 2798-0650

Volume 1 Issue 22021

DOI: $10.36663 /$ joes.v1i2.145

formulation of the research problem. (2) After selecting the data, the researcher displays those data into good sentences. (3) After displaying data, the conclusion is drawn.

\section{Findings}

In the first article, most of the students indicated that they would prefer to and would continue to read books in either format. The students showed no particular preference for reading the books in either format. There was one item of interest subjects indicated that they were impressed with reading the wide selection of e-books and the various features of the computer program. They also indicated that they would like to log into the Raz-Kids website from home and read more books from home. The students did not have difficulty with navigating the books on the computer, and they did not find it confusing.

In the second article, as evidenced by classroom observations and reading levels, the three students responses reflected their low reading achievement and off-task, unmotivated behaviors during classroom reading times. Unlike the other five participants, these three participants frequently engaged in off-task behavior during reading-related tasks. Three students had difficulty focusing independently on printed material for a sustained period of time, and often resorted to fidgety, off-task or disruptive behaviors (i.e., disrupting their neighbors) during their guided, small-group reading sessions with their peers to avoid looking incompetent or to hide their uncertainty about a word. Unlike the independent reading behaviors of the other four participants often stopped reading, did not attempt to independently sound out or guess the word, and instead waited for their teachers' assistance.

In the third article, the results indicated that although the mean scores of experimental group was higher than those of the control group in all of the reading comprehension tests, there were no significant between-group differences in overall performance of reading comprehension test. The data collected from both groups' reading strategy use were calculated and analyzed statistically with independent-samples and paired-samples t-test.

In the fourth article, the level of the questions provided was suitable for the pupils' level as it consisted of lower order thinking skills and high order thinking skills questions. The results showed the improvement of the participants in reading comprehension. Three worksheets were given during the implementation and the participants showed their progress each time they did the worksheets.

In the fifth article, the result shows that students not only improved in reading comprehension ability, but also in their attitude towards reading and the study of English. In accordance with the gained results, the success of an e-book reading and its functionalities, as 


\section{JOES $\mid \begin{aligned} & \text { Journal } \\ & \text { of Educational } \\ & \text { Study }\end{aligned}$}

ISSN 2798-0650

Volume 1 Issue 22021

DOI: 10.36663/joes.v1i2.145

stated above, can be predicted as well, in terms of the benefits and advantages that an e-book is holding. the results reveal that reading an e-book made it possible to have intention, to rouse interest and motivation, to gain confidence and enthusiasm for further reading and for studying English or English written books. It has also improved students' reading achievement and comprehension and attitude toward reading can be promoted when they are allowed to read an ebook which is suitable for their level and interest and are encouraged to get an e-book instruction.

\section{Discussions}

In the first article, the results of the ANOVA yielded interesting results since the students scored significantly lower on the second test based on a book that was read in the same electronic format as the third book. The survey results also indicated that the participants enjoyed the first and third books more than the second book. The format of the book did not matter as much as the level of enjoyment that the children received from the storyline. All three books were read in the same fashion with the children "bump reading" in the same reading groups for each session. The groups also had the same facilitator for each session. The groups also all engaged in the same extension activities after reading each selection. The homogeneous groupings also ensured that their reading levels were comparable. The only difference in the study design was the format of the books. Readings of the print book and the second e-book resulted in comparable amounts of enjoyment and comparable comprehension scores.

In the second article, with the goal to understand grade 1 students' experiences with and attitudes toward reading digital texts in a sociocultural context, this investigation was undertaken as a general qualitative study. Classroom observations revealed that five student participants exhibited diligent, motivated, on-task behaviors during reading, while the exact opposite behavior patterns were observed in the other three student participants. The student participants' behaviors matched their attitudes toward completing such print-based worksheets after reading a story but not toward completing computer-based reading activities.

In the third article, the results of this study did not lend full support to the findings of previous research. The failure to achieve statistical differences in the 3 tests may be due to the following reasons. Firstly, many unknown words appeared in the texts of the electronic storybooks, and each story was taught only for two periods of classes. Therefore, young readers were unable to learn those unfamiliar new words effectively within the instructional period to lead to significant improvement. Secondly, compared with these young readers' textbooks, which were composed of short and simple dialogues, the three electronic storybooks were longer than their textbooks. Thus, it is possible that though reading strategy instruction integrated with e-book helped improve reading comprehension in the experimental group, the familiarity of the vocabulary, the length of texts, and text difficulty may be possible sources resulting in the insignificance of the improvement in reading comprehension. 


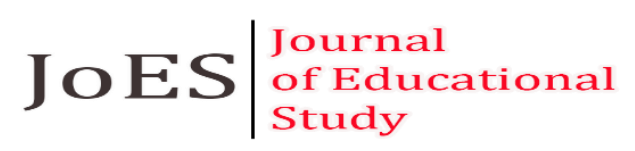

ISSN 2798-0650

Volume 1 Issue 22021

DOI: $10.36663 /$ joes.v1i2.145

In the fourth article, according to Gilakjani (2012) in Yee \& Zainuddin (2018) stated that the studies have shown that computer based multimedia can improve pupils' learning and retention of materials which are presented in class compared to study materials that do not incorporate the use of multimedia. From the implementation, the pupils had showed they could write more correct answers for reading comprehension in the worksheets. It showed that E-book was definitely effective in helping the pupils to comprehend the reading text. they listened attentively.

In the fifth article, regarding e-book's functions, students had an individual taste. The result revealed that $35 \%$ thought highly of interaction, which was a huge benefit that an e-book offered over traditional print. Another $28 \%$ mentioned that multimedia in an e-book could facilitate learning and arouse interest for reading. In fact, it is impossible to get more interactive and visual than the allowance of movie clips in an e-book, and sound can be used for several key pedagogical benefits.

The implication of this study is by introducing English reading for elementary school students using e-book will be very useful for the development of children's literacy in this digital era. According to Yoon (2013), an e-book enables students to get involved in reading, to have motivation, interest and a desire for further study. Another significant reason why an e-book needs to be focused in foreign language class is that it helps to enhance four skills in learning a language in particular. An e-book provides a wealth of authentic written, audio and video material which might be of personal or professional interest to students.

For future study, more research needs to be undertaken on the educational value of an ebook, which can easily be pulled together by many users. At present, there are copious quantities of e-books freely available on the internet, yet despite the rapid IT development, few teachers feel comfortable or believe they have the time to delve into the internet to support their teaching and improve students' learning. It is thus expected for teachers to have a research and training course, in order to recognize the wealth of e-book resources available and how to apply and embed them successfully in their classroom teaching (Yoon, 2013).

\section{Conclusions and Suggestions}

Related to the data that have found in the articles, the implementation of reading English literacy in elementary school was about the teacher that prepare all the necessary needs for learning activities. Based on findings and discussion, researcher found that the interesting way to implement reading English literacy for teacher in the classroom by using e-book, properly in the digital era. Electronic book can make students more interested in reading with many features. The electronic book contained features such as audio pronunciations of words, pop-up glossaries, read-aloud narration, sentence highlighting, and automatic page turning. Electronic storybooks in a digitized form had multimedia effects like written text, oral reading, oral discourse, music, sound effects, 


\section{JOES $\mid \begin{aligned} & \text { Journal } \\ & \text { of Educational } \\ & \text { Study }\end{aligned}$}

ISSN 2798-0650

Volume 1 Issue 22021

DOI: $10.36663 /$ joes.v1i2.145

and animations. Thus, the use of e-book is very useful for students. E-book offers powerful electronic features such as note taking, key word searches, quick navigation, and links to related information. In addition, e-book also consists of graphics, list of vocabularies and so forth. These elements can trigger their interests in order to help them comprehend the input better and they are no longer feeling bored in the class.

The researcher has found some effects of electronic book as a teaching tool on reading literacy in elementary school. Such as the introduction of new media in the form of e-books with features that can help students to prefer reading and reading instruction from teacher that were easy to understand as a form of instruction for using e-book. Multimedia features in e-books can support processing and memory. Furthermore, e-book also develop student's positive attitudes toward reading because their formats were more engaging, interesting, more enjoyable, and motivating to students. E-book was definitely effective in helping the students to comprehend the reading text. In addition, the effects of an e-book reading on the following aspects: 1) vocabulary increase, and 2) the changes of affective factors on learning English through an e-book such as motivation and interest on reading.

Based on this study, researcher has the suggestions as follows: (1) Teachers can use this research as input for implementing and developing electronic book as a teaching tool in learning to read English literacy in elementary school. (2) Students can be helped to improve skills in learning to read English literacy through electronic book as a learning media. (3) Researchers can make the results of this study a useful experience in learning to read English literacy in elementary school.

\section{References}

Ayu, M., Diem, C. D., \& Vianty, M. (2017). Secondary School Students' English Literacy: Use of Interactive Read Aloud Instructional Strategy. International Journal of Applied Linguistics \& English Literature, 6(7), 292-299. http://dx.doi.org/10.7575/aiac.ijalel.v.6n.7p.292

Carter, N., Bryant-Lukosius, D., DiCenso, A., Blythe, J., \& Neville, A. J. (2014). The use of triangulation in qualitative research. National Library of Medicine, 41(5), 545-547. https://doi.org/10.1188/14.ONF.545-547

Ciampa, K. (2012). Reading in the Digital Age: Using Electronic Books as a Teaching Tool for Beginning Readers. Canadian Journal of Learning and Technology, 38(2), 1-26. https://eric.ed.gov/?id=EJ981797

Creswell, J. W. (2012). Educational Research: Planning, Conducting, and Evaluating Quantitative and Qualitative Research (4th ed.). Pearson. http://lcwu.edu.pk/ocd/cfiles/TESOL/MS-TSL505/EducationalResearchPlanningConductingandEvaluatingQuantitativeandQualitativeR esearch.pdf 


\section{JOES $\begin{aligned} & \begin{array}{l}\text { Journal } \\ \text { of Educational } \\ \text { Study }\end{array}\end{aligned}$}

ISSN 2798-0650

Volume 1 Issue 22021

DOI: 10.36663/joes.v1i2.145

Fathi, J. (2020). The Effect of Second Language Reading Strategy Instruction on Young Iranian EFL Learners' Reading Comprehension. International Journal of Instruction, 13(1), 475488. https://doi.org/10.29333/iji.2020.13131a

Fu, Y. J., Chen, S. H., Wey, S.C., \& Chen, S. C. (2014). The Effects of Reading Strategy Instruction via Electronic Storybooks on EFL Young Readers' Reading Performance. International Journal of Contemporary Educational Research, 1(1), 9-20. http://ijcer.net/en/download/article-file/147934

Gilakjani, A. P. (2016). How Can Students Improve Their Reading Comprehension Skill? Journal of Studies in Education, 6(2), 229-240. https://doi.org/10.5296/jse.v6i2.9201

Jones, T., \& Brown, C. (2011). Reading Engagement: A Comparison Between E-Books and Traditional Print Books in an Elementary School. International Journal of Instruction, 4(2), 5-22. https://eric.ed.gov/?id=ED522678

Khairuddiniyah. (2017). The Implementation of Literacy Strategies in Teaching English by the English Teacher at MAN Insan Cindekia Padang Pariaman. English Education: Jurnal Tadris Bahasa Inggris, 10(2), 242-257. https://doi.org/10.24042/ee-jtbi.v10i2.1748

Kharizmi, M. (2015). Kesulitan Siswa Sekolah Dasar Dalam Meningkatkan Kemampuan Literasi. JUPENDAS, 2(2), 11-21. https://media.neliti.com/media/publications/71420-ID-kesulitansiswa-sekolah-dasar-dalam-meni.pdf

Mack, N., Woodsong, C., MacQueen, K. M., Guest, G., \& Namey, E. (2005). Qualitative Research Method: A Data Collector's Field Guide. Family Health International. http://www.intrec.info/Training\%20material/Qualitative\%20methods/Literature/1.\%20fie ldguide.pdf

Murtadho, M. A. (2018). The Descriptive Study of Students' Attitudes on Self-Directed Language Learning Strategy in English Rendezvous Area of UPTPB in IAIN Salatiga. Salatiga: English Education Department of Teacher Training and Education Faculty State Institute for Islamic Studies (IAIN) of Salatiga. repository.perpus.iainsalatiga.ac.id/4276/1/SKRIPSI\%20EDO\%20edit\%20halaman\%20.p df

Sugiyono. (2008). Metode Penelitian Kuantitatif Kualitatif dan R\&D. ALFABETA.

Thanyathamrongkul, R., Singhasiri, W., \& Keyuravong S. (2018). Language literacy, language education policy and classroom practices in a Thai primary school context. Issues in Educational Research, 28(4), 1060-1079. http://www.iier.org.au/iier28/thanyathamrongkul.pdf

Yee, B. C. \& Zainuddin, N. S. (2018). The Use of E-book to Improve Reading Comprehension among Year 4 Pupils. Journal of English Education, 3(1), 23-32. https://doi.org/10.31327/jee.v3i1.477

Yoon, T. (2013). Beyond the traditional reading class: The application of an e-Book in EFL English classroom. International Journal of Research Studies in Language Learning, 2(1), 17-26. https://doi.org/10.5861/ijrsll.2012.93 